\title{
Relationship Between Organizational Ethics and Employee Performance in Airlines Industry: Evidence from Nigeria
}

\author{
Umar Abbas Ibrahim*, Sha'awa Mohammed \\ Department of Business Administration, Nile University of Nigeria, Abuja, Nigeria \\ Email address: \\ abbas.ibrahim a nileuniversity.edu.ng (U. A. Ibrahim), shaawamohdayahoo.com (S. Mohammed) \\ ${ }^{*}$ Corresponding author
}

\section{To cite this article:}

Umar Abbas Ibrahim, Sha'awa Mohammed. Relationship Between Organizational Ethics and Employee Performance in Airlines Industry: Evidence from Nigeria. Science Journal of Business and Management. Vol. 8, No. 1, 2020, pp. 41-49. doi: 10.11648/j.sjbm.20200801.16

Received: January 11, 2020; Accepted: February 17, 2020; Published: February 25, 2020

\begin{abstract}
The need for organizations to achieve set goals and employees' desire for equity have affected etiquette, integrity, self-discipline and by extension the level of performance within the framework of employment relationship. This study therefore examines the effect of organizational ethics on employee performance in Airlines Industry. A survey research design was used based on population of 23 registered domestic airline carriers in Nigeria. Using purposive sampling technique, the scope was limited to the 6 busiest Airline. Judgmental random was used in administering 96 questionnaires to the employees of the 6 selected airline carriers, i.e. 16 employees from each airline. Multiple regression analysis was used in analyzing the data obtained. The study revealed that Organizational discipline, Commitment, and Work attitude positively affect employee's performance in the Airline industry. However, the results suggests that Organizational Teamwork has a negative impact on the performance of Employees, signifying that a unit increase in Teamwork on the average lead to a corresponding unit decrease on employee performance by -0.067 units. Though, this impact is negative it is also statistically insignificant at conventional level. This study concludes that ethics serves as organizations guide and encourage employees to practice good behavior for the sake of improving their performance. The study recommends that management of Airline businesses should strive to see the implementation of organizational ethics that can help them to achieve superior performance in terms of Organizational discipline, Commitment and Work attitude.
\end{abstract}

Keywords: Airline Carriers, Airline Industry, Employee Performance, Organisational Ethics, Organisational Discipline

\section{Introduction}

Organizational Ethical behavior and the prevailing system of employment relations in the workplace is very important for employee performance, general development, the production of goods and services, both for domestic consumption and international trade and the inclusive benefits of sustainable human developments. In other words, how well organizations adhere to ethical standards, obviously, determines the wellbeing of all the stakeholders, the organization's productivity and the subsequent profitability, as well as the macroeconomic growth and development of the nation Adeyeye et. al. cited in Adeyeye et. al, [2]. Within the literature of Organizational ethics, emphasis had been placed on ethical climate in the workplace, due to its influencing employees' perception, and how their organization emphasizes the ethical aspect of business and encourages employees' ethical work behaviors [3]. As stated by Martin and Cullen ethical climate is the employees 'perception of what constitutes ethically right or wrong behavior; thus, ethical climate becomes a psychological mechanism through which ethical issues are managed in an organization [3].

Farouk and Jabeen noted that the significance of an ethical climate to achieve sustained competitive advantage has gained increased scholarly and practitioner interest [4]. There is growing evidence that unethical decisions often undermine the performance of organizations [5]. Organizations are under tremendous pressure to maintain a beneficial ethical climate and to pursue socially responsible behavior [6]. Employees are the critical stakeholders, and they can influence the firm's operations and profitability [7]. Many employees want to be associated with socially responsible organizations [8] and, at the same time, desire that their 
organizations can compete effectively in the marketplace [9]. Thus, any action and procedures contrary to the expectations of these employees would rather hinder the trajectory of production processes and the development of the organizations.

Recent research has shown there is an endemic increase in failed businesses solely based on ethical bankruptcy of organizations. Lings pointed out that there is apparently a very high rate of business failure among small to medium enterprises [10]. It may not be possible to blend the interests of various groups, but through the harmonious relationship between management and employees, corporate bodies and their environments, something could be done to stabilize corporate bodies and prevent them from failure [11]. This problem has birthed the new interest in the study of ethics in workplace and how it affects general performance of organizations. As evidence by the awful experience of Enron, Tyco and WorldCom corporate scandal, organizational ethics is found to be one of the most critical factors affecting not only organizational performance and effectiveness but also its corporate existence and survival [12]. Pan American Airline was at some point, the largest international air carrier and unofficial flag carrier of the United States from 1927 before running into management problems and ultimately declaring bankruptcy on December 4, 1991. As the most prominent in the airline industry, the airline is credited for many innovations that shaped the international airline industry, including the widespread use of jet aircraft, jumbo jets, and computerized reservation systems [13].

There are indications that Nigeria's aviation industry has over time been poorly managed as seen from the inception of the first national carrier airline management agreements between the Nigerian Airways and the Royal Dutch Airline between the 1970's and 1980's. In 1999, bad management led to a crisis in the Nigerian Civil Aviation industry following the decline and near collapse of the Nigerian Airways [14]. As a result of bad management and clear indication of lack of coherent policy, coordination and rationality governing both internal and external affairs, the National carrier was declared bankrupt in 2004. More recently, the Federal Government, under the auspices of the Asset Management Company of Nigeria (AMCON), took over Nigeria's largest domestic airline, Arik Air, due to failed management.

The importance of human capital for the successful operation and maintenance of any competitive industry cannot be over-emphasized. Therefore, and due to the importance organisational ethics in any corporate setting, it is necessary investigate the effect of organizational ethics on employee performance in the Airline industry in Nigeria. The motivation to examine extent to which organizational ethics influences employee's performance of the Airlines Industry in Nigeria was informed by the importance of employees to the success of organisations. It also hinged on the need to specifically seek to examine ways in which airlines have managed Organizational discipline, Organizational Teamwork, Organizational commitment and Work attitude over the period of the recent challenges in the industry, and whether, and to what extent, this has impacted on the performance of employees in that sector.

\section{Literature Review}

\subsection{Concept of Organizational Ethics}

Shahrul et. al. viewed organizational ethics as a cultural norm that advocates people to be held accountable and responsible for the work they do based on the belief that work has intrinsic value to the individual in an organization [15]. For Langlois and Schlegelmilch, an organizational code of ethics is simply a statement of corporate principles, ethics, rules of conduct, code of practice or company philosophy regarding responsibility to employees, shareholders, consumers, the environment or any other aspects of society external to the organization [16]. Similarly, Agboola et. al. [17] describes organizational ethics to be part of the responsibilities of the organization and thus, expected employee commitments enclosed in the core values and principles of the organization. This suggests that, organizational ethics can be widely seen as the guideline an organization and its executives can use to generate sound decisions. This is so because the organizational ethics comprises of the set standards articulated in law and regulations, internal policy, and procedures. For instance, being honest, working with integrity, respect, and fairness are based on the principles, which are expected from employees and customers in terms of service delivery, product quality, health, safety, and efficiency. Various measures of organizational ethics have been used in assessing compliance to certain behaviors and set ethical requirements. Although different organizations set different tools of organizational ethics in achieving their desired vision, the most critical of these measures are reflected in the perspective of organizational discipline, teamwork, organizational commitment and work Attitude.

\subsubsection{Organisational Discipline}

Dumisan viewed discipline to be an observance and total compliance to the rules and regulations of a society, community or organization. Employee perception of an organization is a determining factor of organizational misconduct [18]. When employees believe that their organization is fair, it is unlikely that they will be involved in misconducts [19]. Due to the conflicting interests of employees there is a tendency for behavioral attitudes to deviate from the established rules and regulations of the organizations [20]. Discipline must be instilled to rehabilitate employees' misbehavior due to violation of work policy and standards. Disciplinary guidelines are used for maintaining the work standard that must be adopted by employees. A reasonable level of predictable behavior is expected from employees for the accomplishment of organizational objectives. The lack of adequate disciplinary measures in an organization spurs ineffectiveness and ineptitude on the part of such organization [21]. 


\subsubsection{Organisational Teamwork}

Teamwork is the ability to work together towards a common vision. It is a well-known fact that teamwork is not only the foundation of all successful managements, but the means of improving overall results in organizational productivity. It is that variable that allows common people to attain uncommon results. Teamwork facilitates employees to cooperate with each other, improve their skills and deliver useful response without any dispute between them [22]. The essence of teamwork is to encourage division of labour, specialization and ultimately increased productivity. The importance of teamwork in terms of productivity sees employees coming together to achieve same goals and objective for the good of the organization.

\subsubsection{Organizational Commitment}

The concept of organizational commitment, when used as predictors of employee retention, has become the focus of managers in general and human resources departments in many organizations [23]. Faloye suggested that when organizations can recruit, train, and then retain skilled individuals, the overall stability of the organization is maintained, both in terms of productivity and financial viability [24]. Organizational commitment has been assessed as a controlling factor of employee retention in several studies. Nelson and Quick and Tuna et. al. among others have noted that, the extent of how strongly an individual identifies with an organization is a predictor of the individual's organizational commitment $[25,26]$. Employees who are committed have a sense of purpose that may help them to advance organizational goals and objectives [27]

\subsubsection{Organisational Work Attitude}

Work attitude plays an important role in manipulating the work performances of employees' in organizations. The way people behave in the workplace often relies on how an employee feels about his/her job which implies that understanding the work attitude of an employee is determined by one's behaviour in workplace. Invariably, this ignites the necessity to recognise, measure, and boost employee attitudes towards work. Miradipta and Jie define job attitude as a conviction or predisposition to behave in a certain way at the workplace as a result of an individual experience as well as personality. Organizations, like individuals, can be characterised and observed as rigid, welcoming, earnest, inventive, traditional or otherwise [28]. Such qualities, as well, can serve as aspects to envisage attitudes and behaviours of the people within these organizations [29]. Liao viewed work attitude as a set of behaviour and judgements to work, and such behaviours and thoughts are redirected in form of work involvement and organizational commitment. It is the actions and inactions of employee towards their work that determines performance and productivity [30].

\subsection{Concept of Employee Performance}

Anitha defined employee performance as an indicator of financial or other outcome of the employee that has a direct connection with the performance of the organization as well as its achievement, further revealed that working atmosphere, leadership, team and co-worker relationship, training and career development, reward programme, guidelines and procedures and workstation wellbeing as well as employee engagement are major factors that determine employee performance [31]. According to Ahmad and Shahzad, apparent employee performance embodies the whole belief of the employee about their conduct and contributions to the accomplishment of the organization and further stated that compensation practices, performance evaluation and promotional practices as a determinant of employee performance [32].

Employee's job performance is the level of individual employee productivity in relation to job related behavior or expectations [33], such performance could be judged excellent, good, average or poor when expectations are compared with actual output. Performance in this sense relate to task performance which is behavior oriented depending on the attitude of job holder towards job [34], in the words of Aluko, work behaviour refers to 'all human acts which are exhibited in work situation' [35]. He opines that to have a good performance at a micro level there must be interaction between work and employees. Such interaction involves the behavioural aspect of the work (job content analysis) which if not properly guided could result into deviation from its initial planned activity in the form of poor performance. This guide is called 'work ethic'. When it is strong, it promotes excellent performance of the job but if otherwise, that is weak, poor performance result whether in the short or long run [36].

\subsection{Organizational Ethics and Employee Performance}

It is the obligation of organizations to set guiding principles to direct employees as well as ensuring adherence and positive work attitude. These governing standards are Organizational Ethics. Organizational ethics is the set of values or moral principles regulating an individual's or a profession's conduct. There is a coherent expectation for every employee of an Organization to behave in a manner consistent with Organizational goals and objectives. Earlier studies indicate relationship between organizational ethics and employees' performance. Organizational ethics inherently influences organizational practices which in turn influence employees' performance. Organizational ethics once adhered to, solely has the power to improve organizational performance, employee job satisfaction and a sense of certainty about problem solving. Employers value a strong organizational ethic due to the economic benefits it provides to the organization [37]. This indicates that employees of an organization with insufficient commitment to work, poor organizational discipline and interpersonal skills would impact on the organization's productivity. Adeyeye, et al observed that organizations are in existence to provide goods and services 
to its stakeholders using all human resources available to them. Indeed, organizations advance the progress of countries through output level and performance, efficiency, and productivity, as engendered by the institutional labour or the employees [2].

\subsection{Theoretical Framework}

The relationship between organizational ethics and employee job performance can be best explained by the Labour Process Theory, which was originally formulated by Karl Marx and expanded by Newton and Findlay [38]. The 'labour process' perspective on the ordering of work suggests that managerial action is chiefly motivated by capital-labour relations, by strategies of employers and their agents to try and control and stabilize the 'unruly' element/factor of production, namely living labour. It is assumed that employer buys a mere capacity to work when a worker is hired; an embodied capacity that walks into and out of the workplace and must be managed with consent. Management must control or manage this capacity. In this context, exercises this control in form of laid down organizational ethics that are to be adhered to by employees. This theory is conventionally and rightly listed as one of the analytical resources for Critical Management Studies. Consequently, this gives a comprehensive understanding of the relationship between the study variables and ultimately proffering some insight as to improved change. The theory argued for how organization can move away from the belief in freedom of employees to act the way they want and establish control mechanisms at their disposal. According Adewale, et al (2015) [36] organizations are constantly seeking ways to improve the effectiveness of control mechanisms to achieve job performance. This in a way promote what work behavior will bring about desired level of job performance in the form of organizational ethics.

\subsection{Empirical Review}

Several empirical studies examined the relationship between Organizational Ethics and Employee Performance in both developing and developed countries. For instance, Adeyeye, Adeniji, Osinbanjo \& Oludayo, (2015) [2] examined the effect of etiquette and unethical behaviour on employee commitment and productivity in Nigeria using a descriptive survey research design. The data collected were analyzed through Structural Equation Modelling using descriptive statistics. Findings from their study shows that significant relationship exists between ethical standards and organizational productivity, in Nigeria and that integrity and discipline have negative impact on improved productivity level of the organization, which could be attributed to the nature of these virtues being abstract and could only be seen or observed overtime. Their study recommends that all government agencies such as National Pension Commission (PENCOM), Nigerian Investment Promotion Commission (NIPC), Economic \& Financial Crimes Commission \& Independent Corrupt Practices, etc. saddled with the duty of ensuring etiquette in workplaces, should discharge their responsibilities more diligently and sanction organizations found guilty of unethical conducts in business concern and employment relationships.

Agboola et. al. reviewed that Employee level of productivity is one of the many possible outcomes of ethical issues in an organization [17]. An organization with strong ethical beliefs leads to a greater sense of commitment among its employees. Their paper established the relationship between organizational ethics and employee level of productivity in higher education institution (private university) in Nigeria. The authors utilized both explorative and cross-sectional survey research method to gather the needed information. The gathered data were analyzed with the use of frequency, percentage, standard multiple regression analysis and correlation analysis. The findings of the study revealed that Wasted Time, Leisure, Degree of Gratification, Self-Reliance, Centrality of Work, Hard Work, and Morality are not statistically significant to employee rewards and hours worked. The study recommends that Private universities should embark on creating leisure periods for their faculty in order to increase their level of productivity.

Byoung et. al. examine how an organization's ethical climate positively relates to its financial performance by considering an organization's innovation, a support for innovation and performance evaluation [12]. Data for their study were collected from employees and managers of 41 subsidiaries of a conglomerate in South Korea through survey questionnaires. Their findings indicate that an organization's ethical climate is positively related to financial performance, and its positive relationship is mediated by an organization's innovation. The result also shows that a support for innovation has the moderating effect, such that the positive influence of an organization's ethical climate on its innovation increases when a support for innovation is high. Their study indicates that an organization's ethical climate can be a critical predictor of its innovation as well as financial performance. In this regard, organizations should pay attention to employees' perceptions of the organization's ethical climate.

\section{Results and Discussions}

The study adopted the descriptive survey design. This involved a careful observation of the existing attributes of event to give picture of the population in order to gather relevant answers from knowledgeable employees' ideas. The population of the study is restricted to the 23 registered domestic airline carriers. The purposive sampling procedure was used in selecting airlines with the highest activity level within Abuja to be Arik Air, Dana Air, Azman, Airpeace, Medview, Aero Contractors, for selecting the sample for weighing the opinion of the respondents. 96 well-constructed four-point Likert questionnaires were administered across the staff of the selected airlines comprising of 16 staff of each airlines. The information derived through questionnaire formed the basis for the study.

The dependent variable is Employee Performance. The 
independent variables are Organizational Discipline, Work Attitude, Commitment and Teamwork. The responses of the respondents regarding these variables were coded and fed into the SPSS and then analyzed.

\subsection{Model Specification}

The model for the study is specified as follows:

$$
\mathrm{EMPP}=\beta_{0}+\beta_{1} \mathrm{DISPL}+\beta_{2} \text { TEAMWRK }+\beta_{3} \text { COMMT }+\beta_{4} \text { WRKATT }+\mathrm{u}
$$

Where: EMPP= Employee Performance

DISPL $=$ Organizational Discipline

TEAMWRK $=$ Team Work

COMMT=Organizational Commitment,
WRKATT $=$ Work Attitude

$\mathrm{U}_{\mathrm{t}}=$ Error Term

$\beta_{0}=$ Intercept, $\beta_{1}, \beta_{2}, \ldots \beta_{4}=$ Coefficients of the explanatory Variables

\subsection{Analysis}

\subsubsection{Analysis of the Variables}

Table 1. Organizational Discipline.

\begin{tabular}{|c|c|c|c|c|c|c|c|c|c|c|}
\hline Code & Statements & SA (5) & A (4) & SD (3) & D (2) & Total\% & Mean & SD & t-stat & Remarks \\
\hline DSCP1 & $\begin{array}{l}\text { There are lay down rules and procedures to strictly } \\
\text { adhere to when carrying out your duty }\end{array}$ & $40(41 \%)$ & $39(40 \%)$ & $14(14 \%)$ & $5(5 \%)$ & $98(100)$ & 3.16 & 0.86 & 3.67 & Accepted \\
\hline DSCP2 & Your manager does not tolerate lateness to work & $33(34 \%)$ & $65(66 \%)$ & $0(0 \%)$ & $0(0 \%)$ & $98(100)$ & 3.34 & 0.48 & 6.96 & Accepted \\
\hline DSCP3 & $\begin{array}{l}\text { Your manager does not accept any act of } \\
\text { insubordination }\end{array}$ & $52(53 \%)$ & $46(47 \%)$ & $0(0 \%)$ & $0(0 \%)$ & $98(100)$ & 3.53 & 0.50 & 7.06 & Accepted \\
\hline DSCP4 & $\begin{array}{l}\text { Your manager serves you with querry when you go } \\
\text { wrong }\end{array}$ & $40(41 \%)$ & $34(35 \%)$ & $14(14 \%)$ & $10(10 \%)$ & $98(100)$ & 3.06 & 0.98 & 3.12 & Accepted \\
\hline
\end{tabular}

Table 1 shows the response rate on Organizational Discipline in Airline companies in Nigeria. The result indicates there are laid down rules and procedures to strictly adhere to when carrying out their duty given a mean and $t-$ statistics value of $(\mathrm{M}=3.16 \mathrm{t}$-stat=0.86). Furthermore, the respondents also agreed that their manager does not tolerate lateness to work as evidence by a mean and t-statistics value of $(\mathrm{M}=3.34 ; \mathrm{t}$-stat=6.96). Also, the respondents agreed that their manager does not accept any act of insubordination as supported with a mean and $t$-statistic value of $(M=3.53$; $t$-stat =7.06). Finally, the respondents agree with the perception that they are queried whenever they go wrong in the organization as evidence by a mean and t-statistic value of $(\mathrm{M}=3.06$; $\mathrm{t}$-stat $=3.12)$.

Table 2. Organizational Teamwork.

\begin{tabular}{|c|c|c|c|c|c|c|c|c|c|c|}
\hline Code & Statement & SA (5) & A (4) & SD (3) & D (2) & Total\% & Mean & SD & t-stat & Remarks \\
\hline $\begin{array}{l}\text { TEAMWR } \\
\text { K1 }\end{array}$ & $\begin{array}{l}\text { Often times you perform your task with other } \\
\text { members of the organization }\end{array}$ & $28(29 \%)$ & $36(37 \%)$ & $22(22 \%)$ & $12(12 \%)$ & $98(100)$ & 2.81 & 0.98 & 2.87 & Accepted \\
\hline $\begin{array}{l}\text { TEAMWR } \\
\text { K2 }\end{array}$ & $\begin{array}{l}\text { You are more motivated to work as team than to } \\
\text { work as individual }\end{array}$ & $19(19 \%)$ & $41(42 \%)$ & $20(20 \%)$ & $18(18 \%)$ & $98(100)$ & 2.62 & 1.00 & 2.62 & Accepted \\
\hline $\begin{array}{l}\text { TEAMWR } \\
\text { K3 }\end{array}$ & $\begin{array}{l}\text { Working as a team tends to enhance the } \\
\text { effectiveness and efficiency of your } \\
\text { organization }\end{array}$ & $48(49 \%)$ & $32(33 \%)$ & $18(18 \%)$ & $0(0 \%)$ & $98(100)$ & 3.12 & 1.11 & 2.81 & Accepted \\
\hline
\end{tabular}

Source: Field Survey 2019

Table 2 shows the extent of teamwork exercised by Airline employees in Nigeria. As revealed, the respondents agree that they often perform their task with other members of the organization, as evident by the mean and t-statistic value of $(\mathrm{M}=2.81$; $\mathrm{t}$-stat=2.87). More so, the respondents are of the view that they are more likely motivated to work as a team than to work individually. This is proved by the mean and $t-$ statistic value of $(M=2.62 ; \mathrm{t}$-stat=2.62). The respondents agree that working as a team tends to enhance the effectiveness and efficiency of their organization as seen by the mean and t-statistics of 3.12 and 2.81 respectively. Lastly the respondents also agreed that organization has the culture of creating more teamwork than individual work as evident by a mean and t-statistic value of $(\mathrm{M}=3.20$; $\mathrm{t}$-stat $=4.57)$.

Table 3. Organizational Commitment.

\begin{tabular}{|c|c|c|c|c|c|c|c|c|c|c|}
\hline Code & Statement & SA (5) & A (4) & SD (3) & D (2) & Total\% & Mean & SD & t-stat & Remarks \\
\hline COMMT1 & $\begin{array}{l}\text { Your organization is committed to developing } \\
\text { strong ethical practice }\end{array}$ & $40(41 \%)$ & $37(38 \%)$ & $12(12 \%)$ & $9(9 \%)$ & $98(100)$ & 3.10 & 0.95 & 3.26 & Accepted \\
\hline COMMT2 & $\begin{array}{l}\text { Your organization is committed to improving } \\
\text { working condition of employees }\end{array}$ & $34(35 \%)$ & $30(31 \%)$ & $19(19 \%)$ & $15(15 \%)$ & $98(100)$ & 2.85 & 1.07 & 2.66 & Accepted \\
\hline
\end{tabular}




\begin{tabular}{|c|c|c|c|c|c|c|c|c|c|c|}
\hline Code & Statement & SA (5) & A (4) & SD (3) & D (2) & Total\% & Mean & SD & t-stat & Remarks \\
\hline COMMT3 & $\begin{array}{l}\text { Your organization is committed to enhancing } \\
\text { its efficiency and effectiveness to service } \\
\text { delivery }\end{array}$ & $28(29 \%)$ & $24(25 \%)$ & $22(22 \%)$ & $24(25 \%)$ & $98(100)$ & 2.57 & 1.15 & 2.23 & Accepted \\
\hline COMMT4 & $\begin{array}{l}\text { Your organization develop and support your } \\
\text { personal goal. }\end{array}$ & $39(40 \%)$ & $22(22 \%)$ & $24(25 \%)$ & $13(13 \%)$ & $98(100)$ & 2.89 & 1.08 & 2.68 & Accepted \\
\hline
\end{tabular}

Source: Field Survey 2019

Table 3 shows the extent of Organizational Commitment of Airline carriers in Nigeria. The respondents agree that their organization is committed to developing strong ethical practice, as evident by the mean and $\mathrm{t}$-statistic value of $(\mathrm{M}=3.10$; $\mathrm{t}$ stat=3.26). The respondents are of the view that their organization is committed to improving working condition of employees as supported by the mean and t-statistic value of
$(\mathrm{M}=2.85$; $\mathrm{t}$-stat=2.66). The respondents also agree that their organization is committed to enhancing its efficiency and effectiveness to service delivery as can be seen by the mean and t-statistics of 2.57 and 2.23 respectively. Lastly the respondents concur that the organization develop and support their personal goal as evident by a mean and t-statistic value of $(\mathrm{M}=2.89$; $\mathrm{t}$-stat $=2.68)$.

Table 4. Work Attitude.

\begin{tabular}{|c|c|c|c|c|c|c|c|c|c|c|}
\hline Code & Statement & SA (5) & A (4) & SD (3) & D (2) & Total\% & Mean & SD & t-stat & Remarks \\
\hline WRKATT1 & $\begin{array}{l}\text { Your manager always supervises you to } \\
\text { ensure that you perform your job task }\end{array}$ & $29(30 \%)$ & $36(37 \%)$ & $20(20 \%)$ & $13(13 \%)$ & $98(100)$ & 2.83 & 1.00 & 2.83 & Accepted \\
\hline WRKATT2 & $\begin{array}{l}\text { You rather finish your daily routing task than } \\
\text { to carry it over to next day }\end{array}$ & $35(36 \%)$ & $25(26 \%)$ & $25(26 \%)$ & $13(13 \%)$ & $98(100)$ & 2.84 & 1.06 & 2.68 & epted \\
\hline WRKATT3 & $\begin{array}{l}\text { You take seriousness in discharging your job } \\
\text { task }\end{array}$ & $36(37 \%)$ & $36(37 \%)$ & $10(10 \%)$ & $16(16 \%)$ & $98(100)$ & 2.94 & 1.06 & 2.77 & Accepted \\
\hline WRKATT4 & $\begin{array}{l}\text { My work is the major source of my income } \\
\text { and I do my best to secure it }\end{array}$ & $19(19 \%)$ & $46(47 \%)$ & $17(17 \%)$ & $16(16 \%)$ & $98(100)$ & 2.69 & 0.97 & 2.77 & Accepted \\
\hline
\end{tabular}

Source: Field Survey 2019

Table 4 shows the response rate on Work Attitude of Airline companies in Nigeria. As it can be seen, the analysis shows that employees are of the perception that their managers always supervise them to ensure that they perform their job task given a mean and t-statistics value of $(\mathrm{M}=2.83 \mathrm{t}$-stat=2.83). The respondents further agreed that they rather finish their daily routing task than to carry it over to next day as supported with a mean and t-statistics value of $(\mathrm{M}=2.84$; $\mathrm{t}-\mathrm{stat}=2.68)$. The respondents agreed that they take seriousness in discharging their job task as supported with a mean and t-statistic value of $(\mathrm{M}=2.94$; $\mathrm{t}$ stat $=2.77)$. Finally, the respondents submit their work is their major source of their income and they do their best to secure it. This is also evident by a mean and t-statistic value of $(\mathrm{M}=2.69$; $\mathrm{t}$-stat $=2.77)$.

\subsubsection{Regression Analysis (Inferential Statistics)}

Table 5. Regression Result, Dependent Variable (Employee Performance).

\begin{tabular}{lllll}
\hline Variable & Co-efficient & Standard Error & t-Statistic & P-value \\
\hline C & 0.211 & 0.185 & 0.258 & 0.258 \\
DSCP & 0.041 & 0.217 & 0.851 & 0.851 \\
TEAMWRK & -0.067 & 0.104 & 0.522 & 0.522 \\
COMMT & 0.699 & 0.201 & 0.001 & 0.001 \\
WRKATT & 0.279 & 0.062 & 0 & 0 \\
R $^{2}$ & 0.81 & & & \\
Adj. R & & & & \\
F-statistic & 0.802 & & & \\
Prob. (F-stat.) & 0 & & & \\
\hline
\end{tabular}

Source: Authors computation (SPSS 21)

The effect of organizational ethics on employees' performance of Airline companies in Nigeria was investigated using regression analysis. The regression result reveals that Organizational Discipline (DSCP) exacts a positive effect on the performance of employees. Implying that a unit increasing in Organizational discipline will invariably leads to a unit increase on the performance of employees by 0.041 units. This impact is only positive but statistically insignificant at conventional level as observed by the p-value. The result further shows that Organizational Teamwork (TEAMWRK) has a negative impact on the performance of Employees signifying that a unit increase in Teamwork on the average lead to a corresponding unit decrease on employee performance by -0.067 units. Though, this impact is negative it is also statistically insignificant at conventional level. In addition, Organizational Commitment (COMMT) which has the coefficient of $(\beta=0.699)$ shows that it has positive impact on the performance of employee. The impact is both positive and statistically significant. Finally, Work Attitude (WRKATT) exacts positive effect on the performance of employees in Airline industry in Nigeria. Implying that a unit increase in Employee work attitude will invariably lead to increase in the performance of employees by 0.279 units.

The result shows R-Square value of 0.81 indicating the proportion of variation in Employee's performance is due to the interactions of the independent variables while about still 0.80 is the proportion of variance in Employee performance that is accounted for both Organizational Discipline, Teamwork, Commitment, and Work Attitude after taking care of degree of freedom (df). That F-statistic value of 99.09 gives us enough evidence that the parameter estimates of the regressed model are jointly statistically significant. Their 
validation of the R-squared and Adjusted R-squared further affirmed this by the very low probability value of f-statistic (i.e. 0.000). Thus, the estimated model is fit for both policy formulation and forecast.

\subsubsection{Test of Hypothesis}

The result of the regression analysis is utilized to test for the four null hypotheses earlier stated in the introduction section of this paper.

Hypothesis one

There is no significant relationship between organizational discipline and employee performance in Nigerian Airline industry.

The coefficient value of DSCP shows a positive value of 0.041 , the first null hypothesis fails to be accepted and thus we conclude that organizational discipline positively affects employee performance in Airline industry.

Hypothesis Two

Organizational Teamwork does not positively affect employee performance in Airline industry in Nigeria

Since the beta coefficient of TEAMWRK shows a value of 0.067 , the second null hypothesis hereby fails to be rejected and thus the study conclude that organizational teamwork does not positively affect employee's performance in Airline industry.

Hypothesis Three

Organizational Commitment does not positively affect employee performance in Airline industry in Nigeria

The beta coefficient of COMMT shows a value of 0.699 , the third null hypothesis is failed to be accepted. Therefore, the study indicates that organizational commitment positively affects employee's performance in Airline industry.

Hypothesis Four

Organizational Work attitude does not positively affect employee performance in Airline industry in Nigeria

The fourth hypothesis fails to be accepted on the basis that the beta coefficient value of WRKATT (Work Attitude) 0.279 is positive. This indicates that Work attitude positively affect employee's performance in Airline industry.

\section{Discussion of Findings}

The paper determines the extent to which organizational discipline affects employee performance in Airline industry in Nigeria. Findings emanating from the paper reveal that organizational discipline exact positive effect on employee performance in Airline industry. The implication of this, is that when organizations strives to maintain and ensure that employees work within the confines of laid down rules and procedures, that invariably stimulates employee performance. This finding is in consistence with Adeyeye, et. al. who submits that an organization benefits greatly when its employees demonstrate some measures of discipline at work. In fact, discipline at work promotes strong relationships to succeed and raises an environment of commitment, dedication, keenness and devotion amongst the employees which ultimately results in improved employee performance vis-à-vis organizational performance [2].
Secondly, the study evaluates the extent to which Organizational Teamwork affects employee performance in Airline industry in Nigeria. Finding from the study reveals that organizational teamwork does not positively affect employee performance in Airline industry. What this suggests is that the nature of Airline business in Nigeria does not seemingly require teamwork. This finding however did not support the opinions of Adeyeye et. al., which observed that with teamwork, creativity in an organization can be achieved [2]. This is because employees can have different skills, knowledge and personal attributes and by practical implication, more ideas can be generated, and more creative solutions brought on board thereby leading to better results and thus improve on the organizational performance. Thirdly, this study ascertained the extent to which Organizational Commitment affects employee performance in Airline industry in Nigeria and thus reveals that organizational commitment positively affects employee performance in Airline industry. The implication of this is that, when organization is totally committed to improving and developing its employees by a way of aligning both the organizational goals to go in tandem with the employees personal goal as well as providing motivating working conditions, those employees are most likely to get attached, focus and committed to serving the organization wholeheartedly thereby stimulating their performance. Thus, this collaborate with the submission of Bhatti et. al. who averred that employee commitment can benefit organization in a number of ways which include but not limited to reducing absenteeism, promoting employee active engagement, reducing intention to quite thereby resulting in sustained performance/productivity [39]. The study further assessed the extent to which work attitude affects employee performance in Airline industry in Nigeria, which indicates that Work attitude positively affect employee performance in Airline industry.

\section{Conclusion}

This study examined the effect of organizational ethics on employee performance in Airline industry in Nigeria using some selected Airline Carriers in Nigeria. The study has four specific objectives, which were analyzed and discussed, in section four. Both descriptive and inferential statistics were employed to analyze the data obtained. In view of the findings revealed, this study concludes that organizational discipline, organizational commitment and work attitude positively affects employee performance in Airline industry in Nigeria. However, Organizational teamwork does not positively affect employee performance. This study submits that ethics is an organization guide which encourages employees to practice good behavior for the sake of improving their performance. Thus, the efforts on improving employee performance will no longer rely on compensation and reward system but instead focusing on organization ethics too. It thus suggests that there is the need for the management of Airline businesses to evolve framework on the implementation of organizational ethics, specifically, organizational discipline, organizational commitment and 
work attitude that can help them to achieve superior performance. The study further emphasized on commitment to providing good working environment in order to stimulate employee performance. This is because when employees are satisfied and pleased with their working environments and with what they do, they would become committed and willingly stay in their organizations. While the study assessed the effect of organizational ethics on employee performance in the airline industry, it was also limited to use of survey design, primary data and regression analysis to establish relationship between the variables. This opens the gap of considering other methods for similar study and application of same study to sectors other than the Airline industry.

\section{References}

[1] Adeyeye, J. O. Aina, S. \& Ige, A. (2012). Globalisation and the Transitional Economy: Impacts and Effect on AfricaRegional Growth. European Journal of Globalisation and Development Research, Vol. 9 (1), pgs 176-185.

[2] Adeyeye, O. J., Adeniji, A. A., Osinbanjo, A. O., \& Oludayo, O. O. (2015). Effects of workplace ethics on employees and organisational productivity in Nigeria. International Conference on African Development Issues, (CU-ICADI).

[3] Martin, K. D. and Cullen, J. B. (2006), "Continuities and extensions of ethical climate theory: ameta-analytic review", Journal of Business Ethics, Vol. 69 No. 2, pp. 175-194.

[4] Farouk, S and Jabeen, F (2018) Ethical climate, corporate social responsibility and organizational performance: evidence from the UAE public sector. Social Responsibility Journal. 14 (4) $738-752$.

[5] Pelletier, K. L. and Bligh, M. C. (2006), "Rebounding from corruption: perceptions of ethics program effectiveness in a public sector organization", Journal of Business Ethics, Vol. 67 No. 4, pp. 359-374.

[6] Kapstein, E. B. (2001), "The corporate ethics crusade", Foreign Affairs, Vol. 80 No. 5, pp. 105-119.

[7] Greenwood, M. (2007), "Stakeholder engagement: beyond the myth of corporate responsibility", Journalof Business Ethics, Vol. 74 No. 4, pp. 315-327.

[8] Viswesvaran, C. and Ones, D. S. (2002), "Examining the construct of organizational justice: a Meta analytic evaluation of relations with work attitudes and behaviors", Journal of Business Ethics, Vol. 38No. 3, pp. 198-203.

[9] Lee, E. M., Park, S. and Lee, H. J. (2013b), "Employee perception of CSR activities: its antecedents and consequences", Journal of Business Research, Vol. 66 No. 10, pp. 1716-1724.

[10] Lings, K., 2014, The missing piece: Solving South Africa's economic puzzle, Pan McMillan South Africa, Johannesburg.

[11] Dietz, G. and Gillespie, N. (2012). The recovery of trust: Case studies of organizational failures and trust repair. Institute of Business Ethics (IBE) Occasional Paper 5.

[12] Byoung K. C., Hyoung K. M and Wook K (2013) An organization's ethical climate, innovation, and performance.
Effects of support for innovation and performance evaluation. Management Decision, Journal Emerald Group Publishing Limited 51 (6), pp. 1250-1275.

[13] Guy, N., and Mark W. (1997). "Birth of a Giant". Boeing 747: Design and Development Since 1969. Zenith Imprint. pp. 1213. ISBN 978-0-7603-0280-4.

[14] Akpoghomeh, O. S. (1999) 'The development of air transportation in Nigeria.' Journal of Transport Geography, 7 (2), 135-146.

[15] Shahrul N. S, Mohd-Nur R. A, Siti S. B, Siti S. H (2016). The Relationship between Work Ethics and Job Performance. The European Proceedings of Social and Behavioural Sciences. 3rd International Conference on Business and Economics, 21 -23 September.

[16] Langlois, C. C. \& Schlegelmilch, B. B. (1990). Do Corporate Codes of Ethics reflect national character? Evidence from Europe and the United States. Journal of International Business Studies (Fourth Quarter), 519-536.

[17] Agboola, G. M., Epetimehin, O. S., Akinyele, S. T., Ashipaoloye, F. K (2015) Organizational Ethics and Employee Level of Productivity in Nigerian Private Universities. European Journal of Business and Management. 7 (28) 125-134.

[18] Dumisan, R. (2012). Employee Responsiveness to Disciplinary Actions. Human Relations, 40 (8): 507-52.

[19] De Schrijver, A; Delbeke, K, Maesschalck, J, Pleysier, S., (2010) Fairness, Perceptions and Organizational Misbehavior. The American Review of Public Administration 3, 230-249.

[20] Idris, S. D. \& Alegbeleye, G. I. (2015). Discipline and Organizational Effectiveness: Study of Nigerian Customs Service. Review of Public Administration and Management, 4 (8): 88-107.

[21] Nwosu, O. \& Ugwuera, E. (2015). Staff Discipline in the Nigerian Local Government System. Journal of Humanities and Social Science, 20 (7): 38-45.

[22] Jones, A., Richard, B., Paul, D., Sloane, K., \& Peter, F. (2007). Effectiveness of teambuilding in organization. Journal of management, 5 (3), 35-37.

[23] Idris, A. (2014). Flexible working as an employee retention strategy in developing countries: Malaysian bank managers speak. Journal of Management Research, 14 (2), 71-86.

[24] Faloye, D. O. (2014). Organizational commitment and turnover intentions: Evidence from Nigerian paramilitary organization. International Journal of Business \& Economic Development, 2 (3), 23-34.

[25] Nelson, D. L., \& Quick, J. C. (2008). Understanding organizational behavior. Mason, Australia: Thomson/SouthWestern.

[26] Tuna, M., Ghazzawi, I., Tuna, A., \& Catir, O. (2016) Perceived External Prestige and Organizational Deviance: The Case of Turkey's Hospitality Industry. Forthcoming in the International Journal of Contemporary Hospitality Management (IJCHM), 28 (2), 366- 396.

[27] Tuna, M., Ghazzawi, I., Tuna, A., \& Catir, O. (2011). Transformational leadership and organizational commitment: The case of Turkey's hospitality industry. SAM Advanced Management Journal, 76 (3), 10-25. 
[28] Susanty, A., Miradipta, R., \& Jie, F.,(2013), 'Analysis of the effect of attitude toward works, organizational commitment satisfaction on employee's job performance', European Journal of Business and Social Sciences, vol. 1 no. 10, pp 1564.

[29] George, R., \& Jayan, C. (2013). Moderating Role of Organizational Culture on Job Attitude and Personal Effectiveness. Anvesha 6 (4).

[30] Liao, C. W., Lu, C. Y., Huang, C. K., \& Chiang, T. L. (2012). Work values, work attitude and job performance of green energy industry employees in Taiwan. African Journal of Business Management, 6 (15), 5299-5318.

[31] Anitha, J. (2014). Determinants of employee engagement and their impact on employee performance. International Journal of Productivity and Performance Management, 63 (3), 308323 .

[32] Ahmad, S., \& Shahzad, K. (2011). HRM and employee performance: A case of university teachers of Azad Jammu and Kashmir (AJK) in Pakistan. African Journal of Business Management, 5 (13), 5249.

[33] Babin, B. J., Boles, J. S. and Robin, D. P. (2000), "Representing the perceived ethical work climate among marketing employees", Journal of Academy of Marketing Science, Vol. 28 No. 3, pp. 345-358.

[34] Werner, J. M. (2000), "Implications of OCB and contextual performance for human resource management". Human Resource Management Review, 10 (1), 245-261.

[35] Aluko, M. A (2000), Employee Motivation. An Effective Tool for Enhancing Workers Productivity. Business and Management Journal.

[36] Adewale, O. O., James, O. A., Hezekiah, O. F and Akinrole O. O (2015). Work Ethics and Employees' Job Performance. Journal of Leadership, Accountability and Ethics Vol. 12 (1) 107-117.

[37] Ali, A., \& Falcone, T. (1995). Work ethic in the United States and Canada. Journal of Management Development, 14 (6), 2635 .

[38] Newton, T. and Findlay, P. (1996), "Playing God? The Performance of Appraisal", Human Resource Management Journal, Vol 6 No. 2, pp. 42-58.

[39] Bhatti, K. K, Nawab, S. \& Akbar, A. (2011) Effect of Direct Participation on Organizational Commitment. International Journal of Business and Social Science, Vol. 2 (9), 15-23. 